\title{
Resilient communities? Collapse and recovery of a social-ecological system in Arctic Norway
}

\author{
Else Grete Broderstad $^{1}$ and Einar Eythórsson ${ }^{2}$
}

\begin{abstract}
Fisheries-dependent Sami communities in the Norwegian Arctic face major challenges adapting and responding to socialecological changes. On a local scale, communities and households continually adapt and respond to interacting changes in natural conditions and governance frameworks. Degradation of the marine environment and decline in coastal settlements can move socialecological systems beyond critical thresholds or tipping points, where the system irreversibly enters a different state. We examined the recent social-ecological history of 2 fjords in Finnmark, North Norway, which have coped, over the past 30 years, with the collapse of local fish stocks, harp seal (Pagophilus groenlandicus) and red king crab (Paralithodes camtschaticus) invasions, and increasingly restrictive resource management regimes. Further, we explored similarities and differences in their social-ecological histories and discuss how the concepts of resilience and tipping points can be applied as analytical tools in empirical studies of community response to socialecological change. We show that although the ecological changes in the 2 communities have consisted of similar developments, they have been temporally different in ways that may have affected coping strategies and influenced the available options at different times. The apparent resilience of Sami fishing communities can be understood as the result of response strategies employed by communities and households, and the economic opportunities that have opened up as a result of a combination of ecological change and institutional and political reforms.
\end{abstract}

Key Words: coastal cod; community response; individual vessel quotas; Porsángu; red king crab; resilience, Sami Parliament; tipping points; Várjat vuotna

\section{INTRODUCTION}

According to the Arctic Human Development Report (2004), Arctic societies have a well-deserved reputation for resilience in the face of change. However, what exactly constitutes social resilience in these societies and why some of them are more resilient than others are open questions. Response capabilities of human systems in the face of short- and long-term socialecological changes depend on the capacity of a system to absorb disturbance and reorganize while undergoing change (Folke 2006). We examine the recent social-ecological histories of two coastal Sami communities to discuss how communities respond to changes in ecosystems and governance systems. Ecological and institutional parameters define feasible response strategies, as well as the success of such strategies. An assessment of the ability of communities to successfully cope with these changes, in terms of being able to sustain local fisheries and secure the survival of basic local institutions, is one way to measure social resilience, defined as the capacity to change to maintain identity (Carmack et al. 2012). The communities included in the case studies are situated within a social-ecological system that has gone through dramatic changes in the past three decades: the fisheries communities in Porsángu/Porsanger fjord and Várjat vuotna/Varanger fjord in Finnmark, the northernmost county of Norway. If these changes are irreversible, it is reasonable to assume that they have already stretched the adaptive capacity of the ecological system beyond its limits and moved the system beyond a tipping point into a different state (cf. Wassmann and Lenton 2012, Young 2012). In some cases, however, social systems can adapt, or even benefit, from such changes.

Instead of identifying, as many modeling exercises do, proxy indicators for social resilience and potential tipping points, we look into the adaptive strategies employed by actors and institutions within the communities in response to social- ecological change. The changes in the two communities consisted of similar events that were temporally different in ways that affected the response options available to the communities at different times.

Communities respond to ecological change with different coping and adaptation strategies, but their available options are dependent on interactions between these changes and social structures, writ large. Recovery of an ecosystem does not automatically lead to recovery of a resource-based social system, as exemplified by cases where ecosystem crisis is met by institutional reforms that allow for privatization of use rights and, as a consequence, the benefits from the resources are taken over by nonlocal actors.

Ecological changes that occur within a fjord system are likely to be part of ecological processes happening on a larger geographical scale; marine stocks migrate and fluctuate within a larger habitat and are affected by ecological events outside the fjord system. The same applies to social change: local fisheries are affected by global markets and technological innovations, as well as by resource governance at local, regional, national, or international scales.

We draw up a framework for analysis of community responses to social-ecological changes that includes the connections, over the shorter and longer term, between governance at different levels and adaptive strategies. We also identify changes in the marine ecology in the two fjords and the interactions between ecological and governance changes that have taken place there since the 1980s, as well as the different consequences of those interactions for the fisheries in the two communities. Finally, we discuss whether this type of analysis brings us closer to an understanding of how resilience is constituted in the case-study communities and whether the social-ecological system of which the communities are a part has passed a tipping point and entered a new state. 


\section{METHODS}

We have used data from our previous research supplemented by findings from other published studies. The primary data on ecological changes and fisheries in Porsángu are derived from 18 interviews with fishers/members of fishing households in 2008-2010, as a part of the "Fávllis" project (Andersen and Persen 2011). The interviews were conducted by Svanhild Andersen, Camilla Brattland, and Steinar Nilsen (Centre for Sami Studies) and Einar Eythórsson (Norwegian Institute for Cultural Heritage Research), in collaboration with the Coastal Sami Resource Centre in Porsángu. The data from Unjárga/Nesseby in Várjat vuotna were derived from 38 interviews with active and retired fishers on fisheries history and ecological change conducted by the late Johan Albert Kalstad in 1993-1995 (Kalstad et al. 2011) and 2 interviews with municipal employees in Unjárga in 2005 by Eythórsson as a part of the project "Coastal Sami Landscapes" (Eythórsson 2008). Supplementary information was drawn from 12 interviews with local people in Unjárga in 2010 by Eythórsson as a part of a survey on historical land use for the Finnmark Commission. Although these interviews were directed toward different questions, they are useful as an update on the development in Unjárga compared with the information from Kalstad's interviews from the 1990s. Secondary data are derived from databases on fisheries statistics held by the Directorate of Fisheries (2014) and Statistics Norway (Statistisk sentralbyrå/ Statistics Norway 2014), the Sami Parliament (SP) administration, the Institute for Marine Research, and media reports (NRK Sápmi 2013a,b).

\section{THEORETICAL APPROACH}

The concepts of resilience, adaptive capacity, and tipping points are widely applied in analyses of biophysical systems and ecosystems. Whether a human community is resilient, and holds a high degree of adaptive capacity, concerns the social dynamics within communities and how they relate to the larger society. In Folke's view (2006), resilience should be understood as an ability to innovate and transform, rather than merely to achieve relative stability while absorbing external shocks.

Tipping points are understood as thresholds that constitute a point of no return in the behavior of complex, dynamic systems. Identification of tipping points in advance of their occurrence may be difficult in complex systems, but, once reached, the system will experience significant change(s) that can be documented (Wassmann and Lenton 2012, Young 2012). For example, in an ecosystem in which important species have been depleted to the point where they disappear from the system, a change of state has occurred, as happened when cod was depleted on the Grand Banks, leaving room for other species to take its place. The introduction of an invasive species to a system may also change its composition irreversibly, giving way to a different state. Such changes are seldom fully reversible because the chances of a system returning more or less precisely to some pre-existing state are small.

How local communities respond to abrupt changes over the short and long run will depend on the options that are available and considered relevant under given political, economic, and ecological circumstances. The severity of the consequences of abrupt changes in social-ecological systems, and the ability to adapt, may depend on the timing of ecosystem changes in relation to institutional changes such as fisheries governance reforms. Ecological and institutional changes are not necessarily irreversible; in some cases, local action can modify their outcomes. In other cases, communities run out of options as they face enduring crisis and pass a critical threshold beyond which they are no longer viable as resource-dependent communities. Perry et al. (2011) distinguish between "coping" strategies occurring on the short timescale, allowing for a relatively quick return to previous conditions, and "adaptive" strategies that occur on longer timescales and require more permanent adjustments. Adaptive strategies at the community level are likely to involve a diversity of interactions of local actors with regional and national networks to mobilize resources beyond the community itself.

Chapin et al. (2006) have labeled economic diversification strategies on the household level, such as combining several parttime jobs within the cash sector of the economy with resource harvesting, which is not uncommon in the Arctic region, as characteristic of social and economic resilience. In the case of coastal Sami, Nilsen (1998) notes that, with the help of flexible, mixed-economy household strategies based on long-standing Sami tradition, fjord communities like Porsángu and Ivgu/ Lyngen in Troms County were remarkably adaptable to resource fluctuation in the 1980s. From this perspective, community responses can be understood as the sum of the coping strategies of individual households. A functional community is, however, more than the sum of its households and can potentially act collectively through institutions like municipal councils, political parties, voluntary associations, private companies, and cooperatives. Such institutions are connected to political, economic, and civil society networks, such as management institutions, branch organizations, and funding agencies. Subsequently, we approach the two fjords as distinct socialecological subsystems, showing that changes in these subsystems had specific local characteristics. Successful adaptive strategies may be the result of local actions, but they also depend on which options are available for local actors at the moment of change.

The strategies by which communities respond to social-ecological change (cf. Perry et al. 2011) can be classified according to temporal and spatial scales (Table 1):

1. Coping strategies, local scale, e.g., diversification by individual households.

2. Coping strategies, regional scale, e.g., governmentsupported crisis alleviation.

3. Adaptation strategies, local scale, e.g., municipal support to alternative industries.

4. Adaptation strategies, regional/national scale, e.g., political/ institutional reform.

For our purposes, coping is defined as shorter term responses over periods up to 10 years. Adaptation is understood as longer term responses with a time horizon of more than 10 years. The analysis is based on the assumption that social resilience and adaptive capacity of the case communities can be explained as the result of strategies employed by a range of actors in response to ecological change and governance change. 
Table 1. Temporal and spatial aspects of community responses to social-ecological change.

\begin{tabular}{lll}
\hline \hline $\begin{array}{l}\text { Temporal scale } \\
\text { Spatial scale }\end{array}$ & $\begin{array}{l}\text { Coping strategies } \\
\text { (short term) }\end{array}$ & $\begin{array}{l}\text { Adaptation strategies } \\
\text { (long term) }\end{array}$ \\
\hline Community & (1) Diversification & (3) Flexibility \\
Regional and & (2) Crisis alleviation & (4) Political reform \\
national scale & & \\
\hline
\end{tabular}

\section{SOCIAL-ECOLOGICAL CHANGE IN PORSÁnGU AND VÁRJAT VUOTNA}

\section{The communities}

We refer to the rural coast settlements within the municipalities of Porsángu and Unjárga as "communities." The two case-study communities are located in fjord areas with predominantly coastal Sami populations. In general, the fisheries in these areas have been in steep decline since the $1980 \mathrm{~s}$, a development that is usually attributed to two critical events: the "seal invasion" in the 1980 s and the introduction of vessel quotas in 1990. By comparing the development and outcomes of the fisheries crisis in these apparently similar communities, we examine how the timing and duration of ecological changes and governance changes, as well as the response strategies by local actors to these changes, constitute resilience in these communities.

Unjárga is a municipality located in the inner part of Várjat vuotna in east Finnmark, close to the Russian border. The current population is $\sim 900$ people, predominantly of Sami origin. In the 1900 census, $80 \%$ of the population was registered as Sami, $7 \%$ of Finnish origin, and $13 \%$ Norwegian. In $2009,54 \%$ of the adult population was registered as voters for the SP. The settlements in Unjárga are scattered along the coastline.

Porsángu is a large fjord in central Finnmark. The municipality of Porsángu includes the coastal settlements along the fjord as well as some inland settlements and the municipal center, Leavnja/Lakselv. The population of the municipality is currently 4300 people of mixed ethnic origin. In the 1900 census, $48 \%$ of the population was registered as Sami, $36 \%$ of Finnish origin, and $16 \%$ Norwegian. In $2009,24 \%$ of the adult population was registered as voters for the SP.

Both municipalities are defined as a part of the Sami settlement area, and all inhabitants in this area have, without consideration of ethnic origin, equal opportunity to apply for financial support from the SP and to benefit from policies targeting the Sami settlement area. Historically, the coastal settlements in both fjords have been dependent on marine resources, in combination with animal husbandry, harvesting of terrestrial and freshwater resources, and seasonal waged labor. In both communities, the number of residents has gradually decreased since the 1970s, the average age is rising, and the number of children and young adults is falling. Several primary schools have been closed down during the past decade, and the same is true of grocery stores and fish processing plants, important institutions in every coastal community. Judging from these demographic indicators, we might infer that these communities are heading toward final closure, i.e., that they might already be past the tipping point for survival.

\section{Ecological changes in the fjord systems}

The coastal settlements in Unjárga and Porsángu have experienced significant changes in the fjord ecosystems during the past three decades, including (1) in-migration of harp seals (Pagophilus groenlandicus) from the Arctic Ocean, (2) the disappearance of coastal/fjord cod (Gadus morhua) from its usual spawning sites, (3) the depletion of kelp forests as a result of increased populations of sea urchins (Strongylocentrotus droebachiensis), and (4) in-migration of an alien marine species, the red king crab (Paralithodes camtschaticus). Historical evidence shows that variability in the abundance of fish and other marine resources seems to be a characteristic of these fjord ecosystems; availability of marine resources has fluctuated in seemingly unpredictable cycles.

These four events have occurred in both fjords, but not simultaneously. In 1979, an "invasion" of the Finnmark fjords by a large number of harp seals started in Várjat vuotna and was followed by a total disappearance of cod from the fjord. In the following years, the seals spread westward and reached Porsángu in 1987. In 1989, the harp seals are reported to have left both fjords simultaneously. There is uncertainty about the role of human impact in these events, but marine scientists consider it likely that the depletion of capelin (Mallotus villosus) and cod in the Barents Sea caused a food shortage for the seals, triggering their mass migration to the Finnmark coast. On the other hand, sudden influxes of harp seals in Várjat vuotna are known to have occurred several times in the 19th century, apparently as a result of natural fluctuations unrelated to human impact (Kalstad et al. 2011).

The disappearance of cod from local spawning sites is a wellknown phenomenon in Finnmark (Fig. 1), and local fishermen usually explain it as an effect of excessive fishing by Danish seiners on local cod populations, especially since the 1960s (Eythórsson 1998b, Maurstad and Sundet 1998). Coastal cod is referred to by marine biologists as a specific stock, or a stock complex, separate from Northeast Arctic (NEA) cod (G. morhua), and consisting of a number of distinct populations. If local cod populations are too depleted, the change may prove irreversible, but there have been some examples of cod returning to abandoned spawning sites in the fjords. In the case of Várjat vuotna, cod returned in 1989, after 10 years of absence; in Porsáygu, cod have been absent for 25 years, and only 1 of the spawning sites has barely started to recover (Smiervuotna/Smørfjord). It remains to be seen if cod will ever return to the other spawning sites (Billávuotna/Billefjord and Leaibevuotna/Olderfjord) in the fjord. The coastal cod stock complex has been dramatically reduced since the 1980s and has been listed as severely threatened since 2006 (Artsdatabanken 2006).

An explosive increase in the population of sea urchins, followed by a related depletion of kelp forests, has occurred in large areas along the Norwegian coast since the 1980s, including the two casestudy fjords (Sivertsen 2006). There is little knowledge about the causes of this change or its reversibility. Kelp forests are known to be important habitat for juvenile cod and other fish, and their depletion is likely to have a negative impact on recruitment to local cod populations. In recent years (2008-2012), fishermen in Várjat vuotna have noticed a gradual recovery of kelp forests, whereas in Porsángu little recovery has yet been reported. 
Fig. 1. Porsángu and Várjat vuotna are two of the major fjord areas in Finnmark County. The map shows spawning grounds for Northeast Arctic cod (Gadus morhua), coastal cod, and depleted spawning grounds for coastal cod, based on interviews with 70 fishers in 1996, by social scientist Anita Maurstad and marine biologist Jan H. Sundet (Maurstad and Sundet 1998).

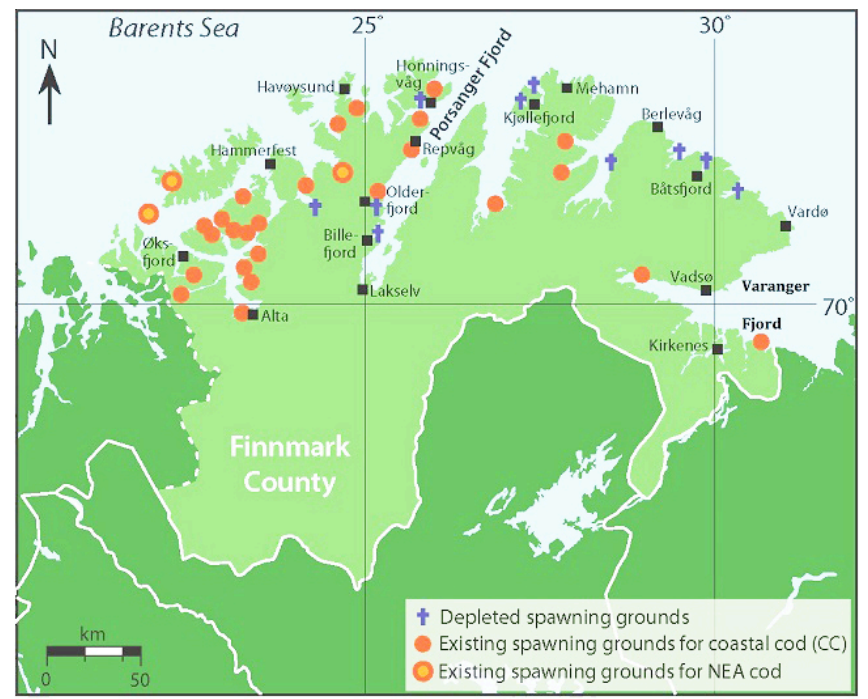

Finally, during the 1960s and 1970s, Russian scientists transported live red king crabs from the Pacific Ocean and released them in the Barents Sea. As the crab population multiplied, it expanded westward into Norwegian waters. Red king crab appeared in the Várjat vuotna in the early 1990s, and a decade later, the crab came to Porsángu. The species is now well established in both fjords. Recent results from biological research indicate that the impact of this invasive species on the bottom fauna in the fjords has been substantial (Sundet and Berenboim 2008).

Except for the introduction of red king crab, the ecological changes described previously may be reversible in the long term. In the case of Várjat vuotna, cod fisheries recovered 10 years after the collapse in 1979, and kelp forests seem to be recovering. In Porsángu, however, the ecosystem has not yet recovered; 2.5 decades after the cod collapse, it remains to be seen whether it will recover to pre-1987 levels. In any case, it can be argued that the introduction of red king crab, which is now a dominant species in Várjat and Porsángu, has irreversibly changed these fjord ecosystems, implying that they have passed a critical threshold to move into a new ecological state.

\section{Changes in fisheries governance}

From the 1980s to the present, the fisheries in both communities have been directly or indirectly affected by several governance changes, ranging from large-scale reform to policies targeting certain species or regions. The motivations for policy changes and reforms have been diverse: response to ecological change, resource protection, improved economic efficiency of the fishery, or political pressure from interest groups. A general assessment of how changes in fisheries governance have affected the fjord communities during the past three decades is beyond our scope. Instead, we have selected three distinct governance changes that are likely to have had an impact on local fisheries in Várjat vuotna and Porsángu: (1) the introduction of individual vessel quotas (IVQs) for the coastal fleet (1990), (2) the development of a new management regime for red king crab (2002-2008), and (3) the introduction of governance measures focusing on the Sami as an indigenous group (1990-2013). By examining how these governance changes, in interaction with ecological changes, have shaped the options that have been available for local actors at different times, we can evaluate their impact on the social resilience of the two fisheries communities.

\section{The effects of individual vessel quotas}

The introduction of IVQs into Norwegian coastal fisheries in 1990 came as a response to a serious decline of the NEA cod stock. Quota allocation was based on vessel catches for the previous three years. In districts that had experienced seal invasions during these years, the result was that very few fishers initially qualified for IVQs. Those who did not qualify had an option to continue as part-time fishers in an "open group fishery." Fishers in the open group were allowed to catch a very limited amount of cod provided that they met certain requirements, such as an upper limit for income from other sources.

The crisis in the cod fisheries came at the same time as the establishment of the SP, which immediately became an important advocate for Sami fishers. As a result, the conditions for part-time fishers in Sami districts were somewhat improved compared to the initial situation in 1990. Although the decline in the fisheries in Sami districts after 1990 is often attributed to the introduction of IVQs, the development in terms of the number of fishers in the two communities from 1988 to 1995 indicates that the picture is not that simple.

As Figure 2 shows, between 1988 and 1995, the number of fulltime fishers in Porsángu declined by $30 \%$, from 68 to 48 , and the number of part-time fishers only slightly declined, from 38 to 34 . In contrast, in Unjárga the number of full-time fishers increased by $9 \%$, from 19 to 21 , and the number of part-time fishers increased by $125 \%$, from 16 to 36 . In Finnmark as a whole, the number of full-time fishers was reduced by $26 \%$, from 2.222 to 1.650, whereas the number of part-time fishers increased by $9 \%$, from 701 to 765 . The development in Porsángu was thus slightly more negative than the average, whereas Unjárga was doing much better than the average. During the following decade, from 1995 to 2005, the number of fishers declined in both fjords, but most dramatically in Porsáygu. In Unjárga, the number of full-time fishers went down $19 \%$, from 21 to 17 , and part-time fishers were reduced by $80 \%$, from 36 to 7 . In Porsáygu, full-time fishers were reduced by $48 \%$, from 48 to 25 , and part-time fishers went down $74 \%$, from 34 to 9 .

The steep decline in numbers of fishermen in the 2 fjords from 1995 to 2005 is probably related to the poor condition of coastal cod and a government-sponsored buyout program aimed at reducing the size of the small-scale fleet. While the buyout program was in operation (2002-2009), 98 vessels from Finnmark County, all $<15 \mathrm{~m}$ in length, were permanently removed from the fishery (Ministry of Fisheries and Coastal Affairs 2009). The decrease in the number of fishers and fishing vessels from 1995 
to 2005 may partially be explained as a long-term effect of IVQs, but other factors, such as ecosystem conditions and the previously mentioned buyout program for small-scale fishing vessels, are also important. During the same period, the number of full-time fishers in Finnmark as a whole went down 32\%, from 1.650 to 1.112 , and the number of part-time fishers was reduced by $41 \%$, from 765 to 454 . Again, Porsángu came out below the average in both categories, and the reduction in full-time fishers in Unjárga was much less than the average. Both communities experienced a massive reduction in the number of part-time fishers.

Fig. 2. Registered fishers in Unjárga and Porsángu, 1985-2012, main and secondary occupation. Source: Directorate of Fisheries (2014).

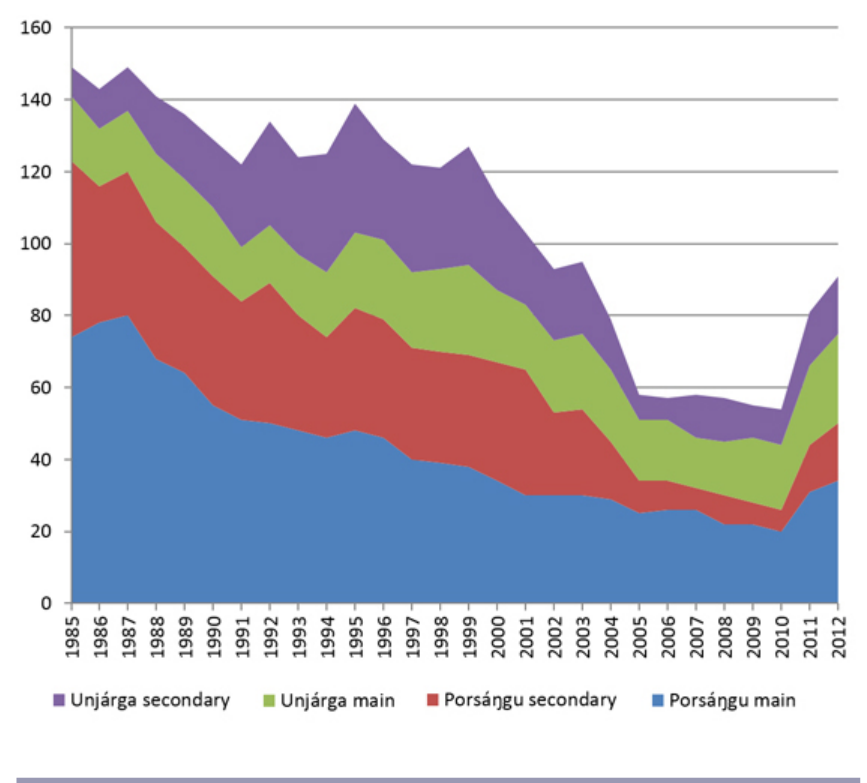

Recently, however, development has moved in another direction. As shown in Figure 2, between 2010 and 2012 the number of fishers in both categories increased in both fjords, reversing the earlier trends and showing a marked deviation from the trend in the Finnmark region as a whole. Porsángu had the largest increase during these 2 years, i.e., 14 full-time fishers $(+70 \%)$ and 10 parttime fishers $(+166 \%)$, and the fishery in Unjárga increased by 7 full-time fishers $(+38 \%)$ and 6 part-time fishers $(+60 \%)$. In Finnmark as a whole, there was an increase in full-time fishers $(+9 \%)$, whereas the number of part-time fishers was reduced $(-6 \%)$. Overall, between 1988 and 2012, the total number of fishers has increased in Unjárga, whereas in Porsáygu the total number in 2012 was still $<50 \%$ of the 1988 number.

It appears then that, contrary to received wisdom, the closing of the fishing commons by the introduction of IVQs in 1990 did not cause an immediate fall in the number of fishers in Unjárga and Porsáygu, nor has the IVQ regime prevented the recent increase in the number of fishers in these communities. The most likely explanation of the different pattern of development in the two communities during the 1990s is the difference in the availability of fish and king crab in the two fjords. In Unjárga the recovery of cod, combined with an influx of king crab, created optimism and a renewed interest in the fisheries in the 1990s; whereas in
Porsángu, the decline in resource availability continued throughout the 1990s. As discussed subsequently, the explanation of the sudden increase in the number of fishers in both communities since 2010 may be found in local actors' responses to a combination of ecological and governance factors.

\section{The management regime for red king crab}

When red king crab first turned up in Norwegian waters, i.e., in Várjat vuotna, in the early 1990s, it was considered a pest; it got tangled in gill nets and caused economic losses for the fishers. Because Russia initially claimed ownership of the stock, a commercial crab fishery was not allowed until 2002. However, from 1994 to 2001, some fishers in Unjárga and the neighboring communities were allowed to engage in a "research fishery," which generated considerable income for the fishers (Jørgensen and Nilssen 2011). In Porsángu, the crab fishery did not start until 2005.

The government allowed the development of a new commercial fishery starting in 2002 that, in the absence of existing traditions and vested interests, included certain fisheries management innovations. In principle, red king crab is an alien species to be kept out of Norwegian waters at all costs. However, fishers in eastern Finnmark have realized the considerable income potential of the fishery, and, as a compromise, commercial fishing has been allowed in a zone east of Davvinjárga/North Cape, whereas only "catch for the purpose of elimination" is allowed in other areas. As red king crab is considered a pest for the traditional cod fishery, a compensation principle was applied in the first allocation of crab quota: only fishers who had caught and delivered a certain quantity of cod in eastern Finnmark could apply for it. As coastal cod was in short supply in the fjords, this rule was unfavorable to small-scale fjord fishers, and many of them were unable to qualify. In 2008, however, after pressure from small-scale fishers, voiced through the SP and the coastal Sami fisheries association "Bivdi," established in 2005, all open group small-scale fishing vessels (i.e., $<11 \mathrm{~m}$ length) that were registered in the "commercial zone" east of Davvinjárga/North Cape were allowed to participate (Ministry of Fisheries and Coastal Affairs 2013a).

The management regime for king crab is thus fundamentally different from that of all other fisheries in Norway: it means that small-scale fishers operating in the open group, who are residents in the "commercial zone," have exclusive access to the fishery. The Norwegian Fishermen's Association initially criticized the arrangement as discriminatory but has now more or less accepted it as an exception to the general rule of equal access to the fishery, irrespective of residence (Norwegian Fishermen's Association 2013). As shown in Figure 3, catches of red king crab have provided a substantial source of income for the Sami small-scale fisheries in the fjords east of Davvinjárga. Moreover, fishing for red king crab and cod can easily be combined, as the fishing seasons are different. The "invasion" of red king crab, combined with a governance innovation, i.e., the management regime of 2008 that favors smallscale fishers, seems to be the most important reason for the apparent revival of the fjord fisheries in Unjárga and Porsángu since 2010. The case of red king crab in eastern Finnmark shows that even if the effects of irreversible ecological changes are diverse and generally regarded as unwanted, in some cases such changes also represent new opportunities for local communities. 
Fig. 3. King crab (Paralithodes camtschaticus) catch (in 1000 Norwegian kroner) landed by vessels below $11 \mathrm{~m}$ from Porsángu and Unjárga, in the period 2000-2012. Municipalities of landings are all over Finnmark, but most of the catch is landed in the vessels' home municipality or close by. Source: Directorate of Fisheries (2014).

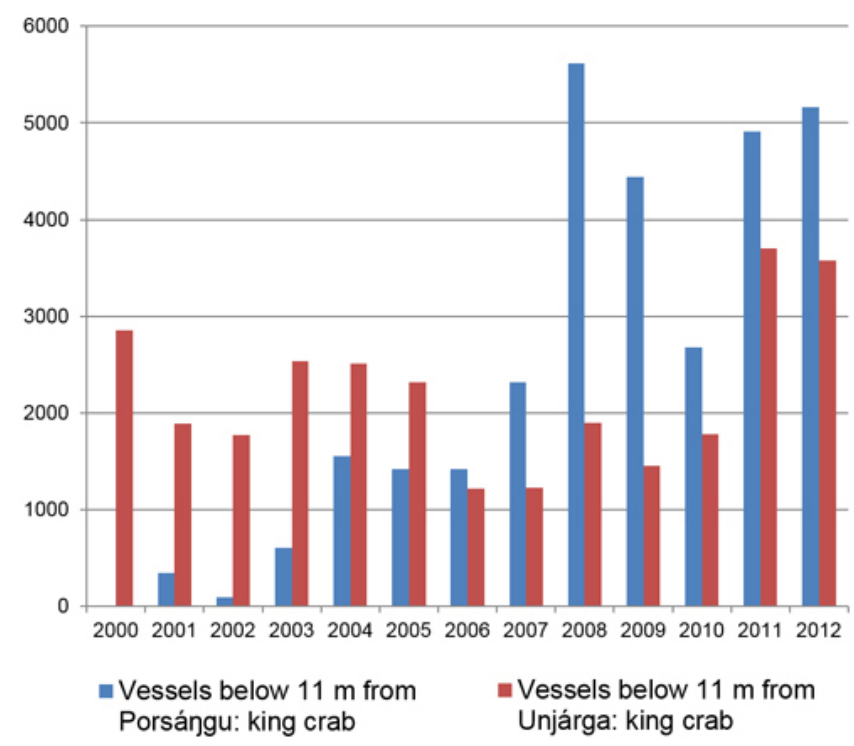

The role of the Sami Parliament in fisheries governance

The SP has had an impact on fisheries governance and the conditions for local fishing communities through financial support and political initiatives. The SP came into existence in 1989, at a time of crisis in the cod fisheries. The fisheries crisis in coastal Sami districts became one of its first core issues (Eythórsson 1998a). The SP soon gained status as a legitimate voice for the concerns of Sami small-scale fishers, a marginalized group within the Norwegian Fishermen's Association (Eythórsson 2003, Brattland 2012). The parliament has been engaged in a long-term political struggle to secure fishing rights and access to the fishery for Sami fishers, and, although the results of the SPs initiatives to reform fisheries policies during the past 20 years have been modest, some progress has been made, as the new management regime for red king crab demonstrates. Since 1990, several reports have been filed on the situation of Sami fishers and Sami indigenous fishing rights. The most recent one, the report of the Coastal Fisheries Commission (CFC), proposed far-reaching fisheries governance reforms in Finnmark (CFC 2008). The CFC proposed to the Ministry of Fisheries and Coastal Affairs that based on a combination of indigenous rights and traditional use rights of the coastal population, a general right to fish for a reasonable livelihood should apply to all residents in coastal Finnmark, either as a full-time occupation or in combination with other income (Jentoft and Brattland 2011, Lätsch 2012).

The ministry did not accept this recommendation. Although it accepted in principle that indigenous rights might apply to the traditional coastal Sami districts, it was not willing to discuss a new institutional framework that would secure Sami participation in fisheries governance in Finnmark, as proposed by the CFC. Instead, the ministry offered certain changes in the fisheries regulations within coastal Sami districts, including an additional cod quota for part-time fishers in these districts and an upper size limit ( $15 \mathrm{~m}$ length) for fishing vessels allowed to operate inside the fjord lines (Ministry of Fisheries and Coastal Affairs 2010, 2011).

According to the 2006 consultation agreement between the SP and the Norwegian government, grounded in International Labour Organization Convention 169 on Indigenous and Tribal Peoples in Independent Countries, the SP has a right to be consulted on all matters of importance for the Sami. In 2010, the SP carried out consultations with the Ministry of Fisheries and Coastal Affairs on the proposal from the CFC. As a compromise, the cod quota allocated to small-scale, open group fishers within the SP subsidy schemes for business development (STN area) was increased, providing improved opportunities for livelihoods based on cod fisheries, combined with other sources of income. The STN is the core area of Sami settlement in Norway and is the target area for special policy measures, governed by the SP. In 2013, for example, the cod quota for each open group vessel up to $11 \mathrm{~m}$ in length within the STN area was considerably higher than for the same category of fishers outside the area, a situation that evoked heated discussions among fishers outside the STN (Grytøyr 2013). In addition, an advisory committee, with some Sami representation, for fjord fisheries was to be established. A majority of SP representatives voted in favor of this compromise, a decision strongly contested among many coastal Sami. A large minority within the SP voted against it, arguing that the concessions offered by the ministry were too small and could easily be withdrawn by future governments.

The SP also distributes investment funds within the STN area. Inhabitants of this area can apply for investment support, i.e., grants and loans, for small-scale enterprises, including small fishing vessels (Ministry of Labor 1996). Unjárga and Porsángu are included in the STN area, and both communities have actively utilized these opportunities (Nygaard and Skålnes 2007) According to Oddleif Nilsen, an employee of the municipal administration in Unjárga (interviewed by E. Eythórsson in 2004), during the 1990s, funds from the SP and municipal funds were applied strategically to reestablish a fishing fleet in Unjárga after a decade with very little fishing activity in the Varanger fjord. As indicated by the figures quoted previously, these efforts were quite successful. In recent years, the SP has also made a number of fisheries-related allocations to Unjárga and Porsángu. In the period 2002-2010, 10 fishery-related allocations went to Unjárga, and 28 of the same category went to Porsáygu. Nineteen of these 38 allocations were used to finance shares in fishing vessels (John Osvald Grønmo, SP administration, unpublished data). The contribution of this funding to the recent increase in the number of fishers in coastal Sami districts has been underlined in several media reports. For example, in 2013, 2 young Sami fishers interviewed by Norwegian Broadcasting Corporation (NRK) Sápmi Radio praised the financial support from the SP as well as other recent changes in fisheries management (NRK Sápmi $2013 a, b)$. 
Regardless of the Norwegian government's failure to accept the CFC's conclusions regarding indigenous fishing rights, there is reason to believe that the sum of governance changes invoked by SP fisheries policies since 1989, investment support for the smallscale fleet, improved access to the cod and red king crab fishery for open group fishers, and better resource protection within the fjord areas through prohibition of fishing with active gear inside the fjord lines have had a significant impact on the fisheries in Unjárga and Porsángu and contributed to the recent rise in the number of fishers. This is clearly demonstrated in the recent increase in catch value, from red king crab and cod, for fishing vessels from Unjárga and Porsángu, shown in Figures 3 and 4.

Fig. 4. Deliveries of cod (in 1000 Norwegian kroner) landed by vessels below $11 \mathrm{~m}$ from Porsángu and Unjárga in the period 2000-2012. Municipalities of landings are all over Finnmark, but most of the catch is landed in the vessels' home municipality or close by. Source: Directorate of Fisheries (2014).

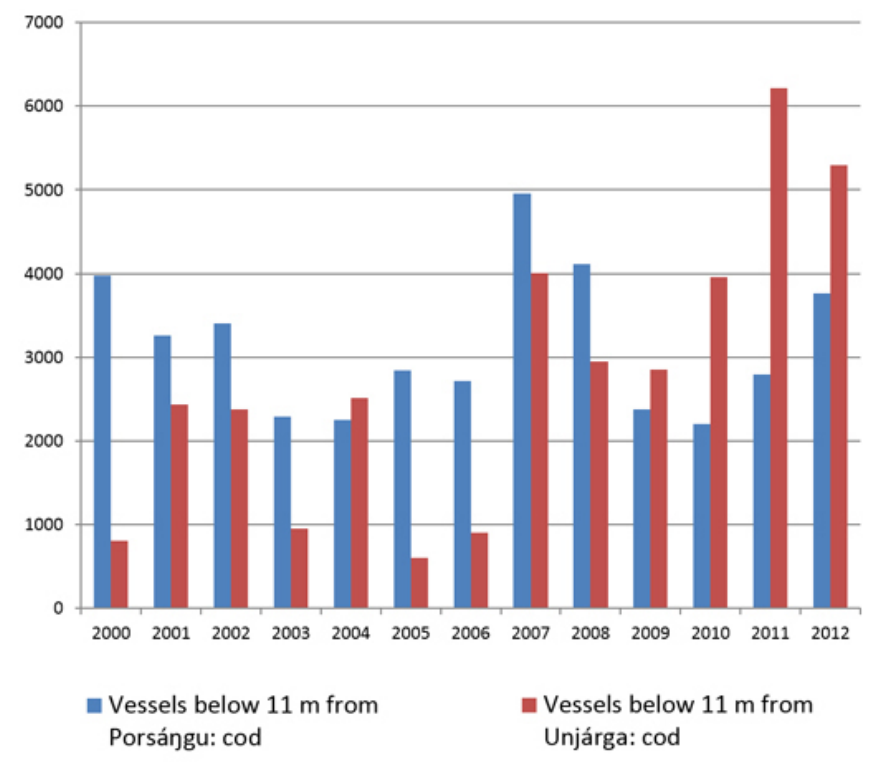

\section{DISCUSSION}

\section{Coping strategies and options}

We have proposed that social resilience at the community level is generated by the responses of local actors to social-ecological change. Using the recent social-ecological history of two fjords as a point of departure, we have described a set of ecological and governance changes that have affected the available response options for these communities. Their subsequent development in the two cases has many similarities, but also significant differences. In particular, the timing of ecological changes has been different; ecological events have co-occurred with governance events in a different fashion in the two fjords. Consequently, the response options available at the time of change were different.

Short-term coping strategies aim at preserving the status quo, allowing the community to "ride out the storm." In coastal communities, the traditional way of coping with poor fishing seasons is diversification, reliance on subsistence selfemployment, and seeking employment in other sectors (cf. Perry et al. 2011). When cod started to return to Várjat vuotna in the 1990s, the IVQ system had left the fishers in Unjárga without any individual quota. Despite this, their fisheries had recovered by the end of the 1990s, and a considerable small-scale fishing fleet was re-established in the area. The municipality of Unjárga followed an active strategy for rebuilding the local fishery by offering grants and inexpensive credit for investment in vessels and quota, in combination with SP funds, and by funding the development of of fisheries infrastructure. During the 1990s, red king crab gradually became a source of income for Unjárga fishers, and, because the cod had returned, the traditional cod fishery could now be combined with the new crab fishery. In Porsángu, the options in the 1990s were different. With a cod crisis starting in the period from 1987 to 1989 and with no alternative commercial species available in the fjord, municipal support and SP funds could not effectively maintain the local fishery until red king crab turned up in 2005. A community strategy that worked effectively in Unjárga did not work in Porsángu because of ecological restraints (Andersen and Persen 2011).

On a national scale, there were certain adjustments of IVQ allocations in the fjord districts in late 1990, and, in the following years, some minor changes were made to ease the situation of open group fishers within the Sami settlement area. These adjustments produced more predictable annual catches for each vessel and higher upper limits of allowable income from other sources for the part-time fishers within the STN area (Ministry of Labour 1996). After 2000, alarming assessments of the situation of the coastal cod stock complex led to new protective measures; namely, fjord lines were introduced in 2004, prohibiting Danish seine fishing in the fjords. Although initially a temporary measure to protect coastal cod (Fiskeridirektoratet 2003), the fjord lines were confirmed as a part of an agreement between the SP and the government in 2011. After the 2013 election, there was a change of government in Norway. Despite the agreement with the SP, the new minister of fisheries has started to hollow out the arrangement for the fjord lines, which could be regarded as a response to larger vessels' interests and pressure from national fisheries organizations (cf. Ministry of Fisheries and Coastal Affairs 2013b). These signals indicate that measures taken to protect small-scale fisheries interests can easily be reversed as a result of changed political priorities. However, the minister admits there needs to be dialogue with the SP before changes can be made in northern fjords where the Sami interests are more significant (Ministry of Fisheries and Coastal Affairs 2013b). However, continuation of these measures depends on political willingness to protect the distinctive small-scale fisheries in these fjords. Thus, they remain coping strategies without a substantial degree of predictability as long as they are lacking a legal foundation along the lines of the CFC recommendation.

\section{Long-term adaptive strategies}

Building on his study of household adaptations conducted in two coastal Sami districts during a fisheries crisis in the 1980s, Nilsen (1998) suggested that flexible adaptations are a long-standing cultural adaptation of coastal Sami communities, based on their extensive experience with fluctuating fjord environments. Provided this is still a relevant attribute of coastal Sami 
communities, it can be understood as a long-term adaptive strategy of these communities. The quick recovery of the fjord fisheries in Unjárga after 1990 was remarkable, and in Porsángu there has been a rapid recovery since 2010 . The swift response to a more favorable social-ecological environment seems to indicate the presence of adaptive capacity and resilience, which is remarkable considering the aging population and the decades of gradual decline of these communities, especially Porsángu (Statistisk sentralbyrå/Statistics Norway 2012).

A shift to more favorable ecological conditions, combined with governance changes that open up more options for local actors despite substantial insecurity, does not automatically generate change at the local scale. The recovery of the fjord fisheries appears to be a result of the strategies of local actors who believe in the future of their communities and the prospects for a livelihood based on local fisheries traditions. However, the adaptive capacity of communities should be understood relative to the large-scale governance frameworks into which the communities are integrated; they are also dependent on larger society in a number of ways that circumscribe the options available to them for responding to ecological change.

Market access, in terms of opportunities for the delivery of fresh fish within a reasonable distance from the fishing grounds in the fjords, has increasingly become a limiting factor for the fjord fisheries during the past two decades. To address the problem of access to fish buyers, the Norwegian Fishermen's Sales Organisation (see Norges Råfisklag 2013), local fishers' organizations, the SP, and the municipalities have supported the development of local delivery stations in the coastal Sami districts. However, local delivery stations depend on larger fish processing companies to buy the catches. With an increasing degree of absentee ownership of the fish processing industry and an abundance of raw fish in the market, deliveries of small quantities from the fjords are not necessarily of much interest to the large processing companies (Trælvik 2011; G. Grytås, unpublished manuscript). As an illustration of the role that the SP can play in contributing to political reforms that address the situation of Sami, and other fishers, the council of the SP has recently raised this issue in a meeting with the minister of fisheries (Kyst og fjord 2013).

The relative success experienced by local actors, in terms of engaging Sami and Norwegian institutions in the issues of coastal Sami livelihoods and access to the fishery for small-scale fishermen in the fjords, reflects a general change in the political influence of the Sami in Norwegian society during the past three decades (Broderstad 2008). The SP's support program for business development is also an example of an institutional and political strategy in support of traditional fisheries as a source of local livelihoods. In sum, it is likely that SP involvement, in the form of economic support and engagement in fisheries policies, has played a major role in preventing the complete elimination of small-scale fisheries from these fjords. Without this involvement, the fisheries in these communities might have passed a politicaleconomic tipping point and ceased to exist.

\section{CONCLUSION}

We set out to explore the dynamic potential of the resilience concept, by applying it to an analysis of social-ecological change in two coastal Sami communities. Our approach was inspired by
Folke (2006:260), who emphasizes that "the resilience approach is concerned with how to persist through continuous development in the face of change and how to innovate and transform into new more desirable configurations." The two fjords have experienced substantial ecological changes that may be characterized as a change of state. The configuration of the fjord systems has changed because of disparate processes: the disappearance of coastal cod from spawning sites, the depletion of kelp forests, and the introduction of an alien species, the red king crab. Combined with changes in fisheries governance, the arrival of red king crab has opened up a new livelihood option for fishers, resulting in a transformation of the fishery that has been beneficial for the communities. Odd as it may seem, an irreversible change in the ecosystem has contributed positively to the reorganization and resilience of the social-ecological system.

We have also described the interaction between ecological change and governance change, including how coping and adaptive strategies are employed in response to unpredictable socialecological changes. The objective of our analysis of the two cases has been to integrate the tools of social science into a resilience perspective. Folke et al. (2005:462) note that "this challenge [the integration of social science] involves linking a broad range of actors at multiple scales to deal with the interrelated dynamics of resources and ecosystems, management systems and social systems as well as uncertainty, unpredictability, and surprise." The task of integrating ecological and social factors in the analysis of resilience is demanding because it requires control of multiple biological and social variables. What can be achieved by using this mode of multidisciplinary analysis is a deeper and more complete understanding of the dynamics that arise at the community level as a result of interaction between biological and social elements within a social-ecological system.

However, what does the analysis tell us about community resilience? Does it imply that coastal Sami communities in general are inherently resilient, or that Unjárga is more resilient than Porsángu? By studying the local effects of ecological change, in combination with fisheries policies and changes in power relations between the Norwegian state and the Sami, for each of these communities, we have found two slightly different varieties of response by local actors within the coastal Sami fisheries when struck by resource decline and negative effects of the 1990 IVQ system. We have also shown that, although the severity and duration of ecological changes in the two fjords have differed, both communities have quickly responded to new opportunities arising from ecological change in the form of cod recovery and the arrival of red king crab. However, these opportunities would not have been available without modifications to the fisheries management regime, such as larger and more predictable catch quotas for open group fishers, the introduction of fjord lines that exclude large vessels and active fishing gear from the fjords, and, in particular, a new management regime for red king crab in 2008 that favors local, small-scale fishers. In most cases, these modifications are specifically targeted toward Sami settlement areas and have come about more or less as a result of political pressure by the SP, which has also contributed financially to renewal of the fisheries in these areas. The apparent resilience of Sami fishing communities is thus closely connected to stronger political representation of the coastal Sami through the SP since 1989. The question of whether the two communities, or the social- 
ecological systems of which they are a part, would have passed a tipping point without that political representation remains hypothetical. In the case of the coastal Sami in Norway, the continued viability and resilience of the fisheries-dependent communities is not only a function of social-ecological dynamics on the local level, but also depends on the political willingness on the level of national policies to support the distinctive small-scale fishery in Sami coastal areas.

Responses to this article can be read online at: http://www.ecologyandsociety.org/issues/responses. $\mathrm{php} / 6533$

\section{Acknowledgments:}

Thanks to Barbara Neis and Rosemary Ommer for valuable comments on the manuscript. Also, thanks to the project Arctic Tipping Points (http://www.eu-atp.org/) for financial support to E. G. Broderstad in an early phase of her writing and to the Norwegian Research Council for funding the "Fávllis" project "Fjord Ecosystems - Sami Communities" (2008-2011). We are also grateful to John Osvald Grønmo at the Sami Parliament for providing data on allocations of SP funds.

\section{LITERATURE CITED}

Andersen, S., and S. Persen, editors. 2011. "Den gang var det jo rikelig med fisk." Lokal kunnskap fra porsanger og andre fjorder. Sjøsamisk kompetansesenter, Indre Billefjord, Norway.

Arctic Human Development Report (AHDR). 2004. Arctic human development report. Stefansson Arctic Institute/The Arctic Council, Akureyri, Iceland.

Artsdatabanken. 2006. Kysttorsk nord for Stad (Gadus morhua). Artsdatabankens faktaark no. 87. [online] URL: http://www2. artsdatabanken.no/faktaark/Faktaark87.pdf

Brattland, C. 2012. Making Sami seascapes matter: ethno-ecological governance in coastal Norway. Dissertation. University of Tromsø, Tromsø, Norway.

Broderstad, E. G. 2008. The bridge-building role of political procedures. Indigenous rights and citizenship rights within and across the borders of the nation-state. Dissertation. University of Tromsø, Tromsø, Norway.

Carmack, E., F. McLaughlin, G. Whiteman, and T. Homer-Dixon. 2012. Detecting and coping with disruptive shocks in Arctic marine systems: a resilience approach to place and people. $A M B I O$ 41:56-65. http://dx.doi.org/10.1007/s13280-011-0225-6

Chapin, F. S., III, M. Hoel, S. R. Carpenter, J. Lubchenco, B. Walker, T. V. Callaghan, C. Folke, S. A. Levin, K.-G. Mäler, C. Nilsson, S. Barrett, F. Berkes, A.-S. Crépin, K. Danell, T. Rosswall, D. Starrett, A. Xepapadeas, and S. A. Zimov. 2006. Building resilience and adaptation to manage Arctic change. AMBIO 35(4):198-202. http:// dx.doi.org/10.1579/0044-7447(2006)35[198:BRAATM]2.0.CO;2

Coastal Fisheries Commission (CFC). 2008. Retten til fiske $i$ havet utenfor Finnmark. Official Norwegian Reports (NOU) 2008: 5. Ministry of Fisheries and Coastal Affairs, Oslo, Norway.
Directorate of Fisheries. 2014. Fiskeridirektoratets statistikkbank [The bank of statistics of the directorate]. Directorate of Fisheries, Bergen, Norway. [online] URL: http://www.fiskeridir. no/fiskeridirektoratets-statistikkbank

Eythórsson, E. 1998a. Hvem skal forvalte ressursene? Forvaltning og rettigheter i fjordområdene i Nord-Norge [Who should manage the resources? Management and rights in the fjord areas in Northern Norway]. Pages 29-51 in I. Bjørklund, editor. Norsk ressursforvaltning og samiske rettighetsforhold. Ad Notam Gyldendal, Oslo, Norway.

Eythórsson, E. 1998b. Voices of the weak - relational aspects of local ecological knowledge in the fisheries. Pages 185-204 in S. Jentoft, editor. Commons in a cold climate: coastal fisheries and reindeer pastoralism in North Norway: the co-management approach. UNESCO and Parthenon, Paris, France.

Eythórsson, E. 2003. The coastal Sami: a 'pariah caste' of the Norwegian fisheries? A reflection on ethnicity and power in Norwegian resource management. Pages 149-162 in S. Jentoft, H. Minde, and R. Nilsen, editors. Indigenous peoples: resource management and global rights. Eburon, Delft, Netherlands.

Eythórsson, E. 2008. Sjøsamene og kampen om fjordressursene [The coastal Sami and the struggle for the fjord resources]. Cállid Lágádus, Kárášjohka, Norway.

Fiskeridirektoratet. 2003. Høyring av forslag til vern av norsk kysttorsk m.v. [online] URL: http://www.fiskeridir.no/fiske-ogfangst/hoeringer/2003/hoering-av-forslag-til-vern-av-norsk-kysttorsk$\underline{\mathrm{m} . \mathrm{V}}$

Folke, C. 2006. Resilience: the emergence of a perspective for social-ecological system analyses. Global Environmental Change 16:253-267. http://dx.doi.org/10.1016/j.gloenvcha.2006.04.002

Folke, C., T. Hahn, P. Olsson, and J. Norberg. 2005. Adaptive governance of social-ecological systems. Annual Review of Environmental Resources 30:441-473. http://dx.doi.org/10.1146/ annurev.energy.30.050504.144511

Grytøyr, G. 2013. Frustrert over "same-kvote." Nord-Salten, 10 January 2013. [online] URL: http://www.nord-salten.no/no/ nyheter/naring/frustrert-over-same-kvote. 10590

Jentoft, S., and C. Brattland 2011. Mot en samisk fiskeriforvaltning [Towards a Sami fisheries management]. Pages 335-345 in S. Jentoft, J.-I. Nergård, and K. A. Røvik, editors. Hvor går Nord-Norge? Tidsbilder fra en landsdel I forandring. Orkana Akademisk, Stamsund, Norland, Norway.

Jørgensen, L. L., and E. M. Nilssen. 2011. The invasive history, impact and management of the red king crab Paralithodes camtschaticus off the coast of Norway. Pages 521-536 in B. S. Galil, P. F. Clark, and J. T. Carlton, editors. In the wrong placealien marine crustaceans: distribution, biology and impacts. Invading Nature - Springer Series in Invasion Ecology, Volume 6. Springer, Dordrecht, Netherlands. http://dx.doi. org/10.1007/978-94-007-0591-3 18

Kalstad, J. A., I. Bjørklund, and E. Eythórsson. 2011. Fiske, fangst og tradisjonell kunnskap i indre Varanger. Tromsø Museums skrifter XXXII. Tromsø Museum, Tromsø, Norway. 
Kyst og fjord. 2013. Vil diskutere fiskemottak. 12 December 2013. [online] URL: http://www.kystogfjord.no/nyheter/forsiden/Vildiskutere-fiskemottak

Lätsch, A. 2012. Coastal Sami revitalization and rights claims in Finnmark (North Norway) - two aspects of one issue? Pages 60-84 in S. Andersen, editor. Fávllis. Innblikk $i$ et forskningsprosjekt om lokal fjordkunnskap. Senter for samiske studier, skriftserie Nr. 18. Universitetet i Tromsø, Tromsø, Norway. [online] URL: http://septentrio.uit.no/index.php/ samskrift/article/view/2356

Maurstad, A., and J. Sundet. 1998. Den usynlige torsken-forskerog fiskerkunnskap om lokale fiskeressurser. Pages 9-25 in B. K. Sagdahl, editor. Fjordressurser og reguleringspolitikk. En utfordring for kystkommuner? Kommuneforlaget, Oslo, Norway.

Ministry of Fisheries and Coastal Affairs (Fiskeri- og kystdepartementet). 2009. Evaluering av Strukturfondet og kondemneringsordningen for kapasitetstilpasning av fiskeflàten [An evaluation of the Structure Fund and buy-out program for the fishing fleet]. Report, May 2009. Ministry of Fisheries and Coastal Affairs, Oslo, Norway.

Ministry of Fisheries and Coastal Affairs (Fiskeri- og kystdepartementet). 2010. Vern av kysttorsk 2010. Ministry of Fisheries and Coastal Affairs, Oslo, Norway. [online] URL: http:// lovdata.no/static/LTI/ltavd1/filer/grafikk/sf-20111215-1346-02-01. pdf

Ministry of Fisheries and Coastal Affairs (Fiskeri- og kystdepartementet). 2011. Stortingsproposisjon 70 L (20112012): Endringar i deltakerloven, havressurslova og finnmarksloven (kystfiskeutvalet). Tilråding frå Fiskeri- og kystdepartementet 16 mars 2012, godkjend i statsråd same dagen. Ministry of Fisheries and Coastal Affairs, Oslo, Norway.

Ministry of Fisheries and Coastal Affairs (Fiskeri- og kystdepartementet). 2013a. Forskrift om regulering av fangst av kongekrabbe $i$ kvoteregulert område ost for 26 grader $\varnothing \mathrm{mv} . i$ 2013/2014. Ministry of Fisheries and Coastal Affairs, Oslo, Norway. [online] URL: http://www.regjeringen.no/nb/dep/fkd/ dok/lover_regler/forskrifter/2013/forskrift-om-regulering-av-fangstav-kon.html?id=733086.

Ministry of Fisheries and Coastal Affairs (Fiskeri- og kystdepartementet). 2013b. Tale til landsmotet $i$ Norges fiskarlag, 13.11.2013 [Speech by the minister to the Norwegian Fishermen's Association]. Ministry of Fisheries and Coastal Affairs, Oslo, Norway. [online] URL: http://www.regjeringen.no/nb/dep/fkd/ aktuelt/taler-og-artikler/ministeren/taler-og-artikler-av-fiskeriminister$\underline{\text { eli/2013/landsmotet-i-norges-fiskarlag.html?id }=745490}$

Ministry of Labour (Arbeidsdepartementet). 1996. Stortingsmelding $n r$. 41 (1996-97) Om norsk samepolitikk. Elanders, Oslo, Norway. [online] URL: http://www.regjeringen.no/nb/dep/ad/dok/regpubl/ stmeld/19961997/stmeld-nr-41-1996-97-/15/7.html?id=315056

Nilsen, R. 1998. Fjordfiskere og ressursbruk i nord. Ad Notam Gyldendal AS, Oslo, Norway.

Norges Råfisklag. 2013. Vedtekter støttefond [Support fund for delivery points and service stations]. Norges Råfisklag, Tromsø, Norway. [online] URL: http://www.rafisklaget.no/portal/page/ portal/NR/Salgavfangst/Stottetilmottak
Norwegian Broadcasting Corporation (NRK) Sápmi. 2013a. De har aren for at det blir flere fiskere [radio]. 5 February 2013. [online] URL: $\underline{\text { http://www.nrk.no/kanal/nrk sapmi/1.10899563 }}$

Norwegian Broadcasting Corporation (NRK) Sápmi. $2013 b$. Glad for å få flere yrkesbrødre [radio]. 24 January 2013. [online] URL: http://www.nrk.no/kanal/nrk sapmi/1.10885397

Norwegian Fishermen's Association. 2013. Fangst av kongekrabbe $i$ kvoteregulert område 2013/2014. A letter to the Directorate for Fisheries, 18 June 2013. [online] URL: http://www. fiskeridir.no/fiske-og-fangst/hoeringer/2013/forslag-til-reguleringav-kongekrabbe

Nygaard, V., and S. Skålnes. 2007. Evaluering av tilskuddsordningen for Samisk utviklingsfond. Northern Research Institute (NORUT) Report Number 7. NORUT, Áltá, Finnmark, Norway.

Perry, I. R., R. E. Ommer, M. Barange, S. Jentoft, B. Neis., and U. R. Sumaila. 2011. Marine social-ecological responses to environmental change and the impacts of globalization. Fish and Fisheries 12(4):427-450. http://dx.doi.org/10.1111/j.1467-2979.2010.00402. $\underline{x}$

Sivertsen, K. 2006. Overgrazing of kelp beds along the coast of Norway. Journal of Applied Phycology 18(3-5):599-610. http://dx. doi.org/10.1007/s10811-006-9064-4

Statistisk sentralbyrå/Statistics Norway. 2012. Samisk statistikk 2012. Statistisk sentralbyrå/Statistics Norway, Oslo-Kongsvinger, Norway. [online] URL: http://www.ssb.no/befolkning/artiklerog-publikasjoner/samisk-statistikk-2012

Statistisk sentralbyrå/Statistics Norway. 2014. Samisk statistikk 2014. Statistisk sentralbyrå/Statistics Norway, Oslo-Kongsvinger, Norway. [online] URL: http://www.ssb.no/befolkning/artiklerog-publikasjoner/samisk-statistikk-2014?fane=om\#content

Sundet, J. H., and B. Berenboim, editors. 2008. Research on the red king crab (Paralithodes camtschaticus) from the Barents Sea in 2005-2007. Institute for Marine Research and Polar Research Institute of Marine Fisheries and Oceanography (PINRO), Bergen, Norway.

Trælvik, E.-B. 2011. Er det så viktig hvor eieren bor? Fortellinger fra Husøy og Berlevåg om betydningen av eierskap i fiskeindustrien. Dissertation. University of Tromsø, Tromsø, Norway.

Wassmann, P., and T. M. Lenton. 2012. Arctic tipping points in an earth system perspective. $A M B I O$ 41(1):1-9. http://dx.doi. org/10.1007/s13280-011-0230-9

Young, O. R. 2012. Arctic tipping points: governance in turbulent times. AMBIO 41(1):75-84. http://dx.doi.org/10.1007/s13280-011-0227-4 